\title{
Acquiring Arabic Vocabularies Through Memorizing Al-Qur'an
}

\author{
Mar'atus Sholehah \\ Syarif Hidayatullah State Islamic University Jakarta, J1. Ir. H. Djuanda 95, Ciputat, Indonesia \\ Corresponding e-mail: m.sholehah15@gmail.com
}

\begin{abstract}
This research investigated acquiring Arabic vocabularies through memorizing al-Qur'an. The language of alQur'an is Arabic. It could not be changed until the end of this world. There are many memorizers al-Qur'an, the frequency in memorizing al-Qur'an for each person is different based on their Arabic ability or their motivation. From this case, the researcher interest to investigate their knowledge of every single word that they have memorized. Based on the background of the problem, the research purposes were used to answer these three questions, namely "How participants acquire Arabic Vocabularies through memorizing alQur'an?", "How parents' role in improving participants' Arabic vocabularies?", And "How Environment affect participants' Arabic vocabularies?". There are three participants from the cluster VI were conducted in this research. This research was conducted with a single case study. To collect the data, the researcher used setting or nature condition, primary and secondary source data, and the most data that got from observation and interview. The steps of data collection are data reduction, data display, and conclusion drawing/ verification. Trustworthiness used in this study to make it reliable and valid. She drew the conclusion based on the findings and discussions; it can be concluded that there are two findings. The first, the participants were able to acquire the meaning of $64 \%$ words ( 5.680 words from 8.897 words) that they memorized. They acquire Arabic words through memorizing al-Qur'an with reading the texts more and more. Then, they always imagine the story that related with the surah's context. The second, the participants' parents have no role in affecting participants' in acquiring Arabic vocabularies. The third finding, friends, and environments have a role in affecting participants' in acquiring Arabic vocabularies. This research expected can be useful for all of the readers, especially for learners and next researchers who are interested to make research in same field namely SLA. I hope, the further researcher be better, more wonderful, and more complete in analyzing data.
\end{abstract}

Key Words: Arabic vocabularies; L2 Acquisition; and memorizing al-Qur'an.

\section{INTRODUCTION}

There have been a lot of studies and debates on the best ways of learning vocabulary. Research on first language acquisition has shown that children learn a lot of words during their primary and secondary education; after graduated, they got 40,000 words (Nagy and Herman, 1987, p. 21 cited in Daskalovska, 2014 , p. 2), which means that they learn about 2,000 to 3,000 words a year. One of the ways of learning vocabulary is by formal instruction in the classroom.

Several direct procedures for learning vocabulary, such using interesting method, using word cards, exercises with synonyms, classification of words, creating semantic maps, using definitions, and so on, have produced best results. However, classroom observations have shown that explicit instruction can help learners acquire about 200 to 300 words a year, so that the logical conclusion would be that the big increase in the learners' vocabulary sizes must be a result of other ways of acquiring vocabulary. Nagy \& Herman (1987, p. 33) cited in Dasklovska (2014, p. 2). Point out that even though explicit vocabulary learning can be effective, we need to take into account the limitations of such instruction as it cannot contribute to the considerable increase in learners' vocabulary knowledge. Thus, it is reasonable to believe that the majority of words are acquired through listening and reading (Nagy et al., 1987, p. 238 cited in Daskalovska, 2014, p. 2). The activity of memorizing categorized as reading.

The language of al-Qur'an is Arabic. It could not be changed until the end of this world. There are many memorizers al-Qur'an, the frequency in memorizing al-Qur'an for each person is different based on their Arabic ability or their motivation. From this case, the researcher interest to investigate their knowledge of every single word that they have memorized. 
Daarul Qur'an is a boarding school where the students memorize al-Qur'an and using Arabic and English languages as its official languages. They drill their languages ability by practicing. Time of tahfizh activity divided into two times, in the morning after praying subuh and in the afternoon after praying Ashar. Tahfizh becomes compulsory in this boarding school. There is some cluster of tahfizh class, one of them is class VI. This cluster is the highest class below sanad class. Students who are of the members of this cluster are students who have memorized 25 parts of al-Qur'an. Thus, they almost complete their memorizing. Maulidia Ayu Permadani, Aisyah Sholeh, and Tanti Rostiana are the members of this cluster.

Their ability both of memorizing and Arabic language is very good. Participants' were recommended by their Tahfizh teacher (Miss. Ni'mah) and the chief of Tahfizh in this boarding school.

Based on elaboration above, the researcher will research entitled "Acquiring Arabic vocabularies through memorizing al-Qur'an".

\section{LANGUAGE ACQUISITION}

Yule (2006, p. 162) states that the term of acquisition refers to the gradual development of ability in language by using it naturally in communicative situations with others who know it.

\subsection{Second Language Acquisition}

Ellis (2003, p. 3) states that the definition second language acquisition divided into two terms, "second" and "second language (L2) acquisition. The term of "second" means any language that is learned after the mother tongue; it can be referred to a third or fourth language. But, it is not intended to contrast with a foreign language. Thus, whether people are learning a language naturally because of living in a country where it is spoken or learning, it called by "second" language acquisition. Then, the term of "L2 acquisition" defined as the way in which people learn the language other than mother tongue in unconsciously process, either inside or outside the classroom.

\subsection{Second Language Vocabulary Acquisition and Learning}

Second language vocabulary acquisition is the unconscious process for getting vocabularies in the second language. Error correction and explicit teaching of rules are not relevant to language acquisition (Brown and Hanlon, 1970; Brown, Cazden, and Bellugi, 1973; cited in Krashen 2002: 1). But caretakers and native speakers can modify their utterances addressed to acquirers to help them understand, and these modifications are thought to help the acquisition process (Snow and Ferguson, 1977; cited in Krashen 2002, p. 1).
While, learning is the opposite of the acquisition. It refers to apply a more conscious process of accumulating knowledge of the features, such as vocabulary and grammar. An institutional setting could not be acquired, it only getting by learning, the example is mathematics. (Yule, 2006: 163). Krashen (2002: 2) said that it helped a great deal by using error correction and the presentation of explicit rules (Krashen and Seliger, 1975 cited in Krashen, 2002: 2). Error correction it is maintained, helps the learner come to the correct mental representation of the linguistic generalization. Whether such feedback has this effect to a significant degree remains an open question (Fanselow, 1977; Long, 1977 cited in Krashen, 2002: 2). No invariant order of learning is claimed, although syllabi implicitly claim that learners proceed from simple to complex, a sequence that may not be identical to the acquisition sequence.

\section{RELEVANT STUDIES}

Four previous studies on some issue have been found. It directed to find out the factors that have contribute or will contribute to the improvement of SLA. There are four factors of previous studies. They are Crookes (1997), Helms-Park (2003), Brown (2010), Lyster \& Saito (2010), Rognori and Xavier (2012), Coyle and Gracia (2014), and Daskalovska (2014).

Crookes (1997) investigated SLA and foreign language teaching. He found that a practical relationship between SLA research and second/ foreign language pedagogy depends particulary on the condition of S/ FL teachers.

Helms-Park (2003) investigated attributes verb serialization in the interlanguage of Vietnamesespeaking ESL learners to language transfer. The finding of this study shown that data were elicited from speakers of a serializing language and speakers of a nonserializing language via a verb-based test greatly facilitated the identification of SVC-related transfer effects.

Brown (2010) investigated "Vocabulary knowledge and Comprehension in Second Language Text Processing: A Reciprocal Relationship?" He reported that the relationship between vocabulary knowledge and reading comprehension is reciprocal in second language reading.

Lyster \& Saito (2010) investigated oral feedback in classroom SLA. The results of this study revealed that $\mathrm{CF}$ had significant and durable effects on target language development.

Rognori and Xavier (2012) investigated "Thematic clustering in second language vocabulary learning scenarios versus mental scenes development." They reported that no significant difference between the subjects' accuracy scores, although the very high accuracy scores in both conditions prove once again the effectiveness of thematic clustering in L2 vocabulary learning.

Coyle and Gracia (2014) investigated "Using songs to enhance L2 vocabulary acquisition in preschool children." They reported that some evidence that songs can be a valuable resource for teaching 
English to preschool learners. Songs can help to motivate children and focus their attention on keywords, thus providing them with the 'building blocks' needed for communication.

Daskalovska (2014) investigated "Reading and vocabulary acquisition." The study found the similar relationship between the learning gain scores and the participants' vocabulary sizes, but different effects of word frequency for the participants with the smallest vocabulary sizes, but different effects of words frequency for the participants with the smallest vocabulary sizes.

Daskalovska's study (2014) has the closest investigation with this study. However, this study will analyze a different factor from their studies, namely acquiring Arabic vocabularies through memorizing alQur'an". From four previous studies, it seems that is not yet to carry out SLA analysis of this study entitled "Acquiring Arabic Vocabularies through Memorizing al-Qur'an."

\section{METHOD}

A single case study is a design of this qualitative research. Because the researcher will analyze the single-case study of acquiring Arabic vocabularies through memorizing al-Qur'an (Yin, 2003, p. 40).

This study addresses these questions. The first, How participants acquire Arabic Vocabularies through memorizing al-Qur'an? The second, How parents' role in improving participants' Arabic vocabularies? The third, How Environment affect participants' Arabic vocabularies?

The research conducted at Daarul Qur'an for holy Qur'an memorization. The choosing of participants based on the consultation to chief of Tahfizh at that place. They are the best one because their abilities in memorizing al-Qur'an faster than others. While observation process, they are in progress in finishing their memorizing. Maulidia Ayu Permadani, Aisyah Sholeh, and Tanti Rostiana are the subjects of this study.

\subsection{Instrument of Research}

The instrument of this qualitative research is the researcher herself (Sugiyono, 2011, p. 292 cited in Naserieh, 2013, p. 31). The researcher becomes the instrument who spends her time for observing, interviewing and analyzing the subjects. Zuriyah (2016, p. 172) cited in Naserieh (2013, p. 31) states that instrument of research is used to collect the data.

\subsection{Procedure of Data Collection}

There are some techniques in collecting the data of this study. In this study, the researcher used setting, primary and secondary source data, and the most data that got from observation and interview

\subsection{Observation}

The instrument of observation is diary book and observation guide-line. I will observe the physical setting, the participants, and their activities (Merriam, 2009, p. 120-121).

Table 1. Observation Sheet

\begin{tabular}{cl}
\hline No. & \multicolumn{1}{c}{ Indicators } \\
\hline 1 & Date of observation \\
2 & Time of observation \\
3 & Surah and verse that memorized by participants \\
4 & Investigating total words that have memorized by \\
& $\begin{array}{l}\text { participants } \\
5\end{array}$ \\
& $\begin{array}{l}\text { Investigating total Arabic words that acquire by } \\
\text { participants while memorizing al-Qur'an }\end{array}$ \\
\hline
\end{tabular}

Adapted from Merriam 2009, p. 120-121.

\subsection{Interview}

To make sure the data, the research will interview participants by using depth interview with multiple questions to investigate their learning-styles (Merriam, 2009, p. 100). This interview is necessary to know past events that are possible to replicate (Merriam, 2009, p. 88).

Table 2. Interview Guideline

\begin{tabular}{|c|c|}
\hline Interviewee & Outline \\
\hline $\begin{array}{l}\text { Tanti Rostiana, } \\
\text { Maulidia Ayu } \\
\text { Permadani, } \\
\text { and Aisyah } \\
\text { Sholeh }\end{array}$ & $\begin{array}{l}\text { 1. To know participants' profile } \\
\text { 2. To know when they begin to } \\
\text { memorize al-Qur'an } \\
\text { 3. To discover their Arabic-language } \\
\text { knowledge } \\
\text { 4. To discover their process to acquire } \\
\text { Arabic vocabularies through } \\
\text { memorizing al-Qur'an } \\
\text { 5. To discover their parent's role in } \\
\text { affecting participant's ability to } \\
\text { know about the Arabic language } \\
\text { 6. To investigate the role of their } \\
\text { friends and environment in acquiring } \\
\text { Arabic vocabularies }\end{array}$ \\
\hline
\end{tabular}

(Adapted from Merriam, 2009, p. 88)

\subsection{Technique of Data Analysis}

In collecting data, I will current flow these three activities, namely data reduction, data display, and conclusion drawing/ verification 


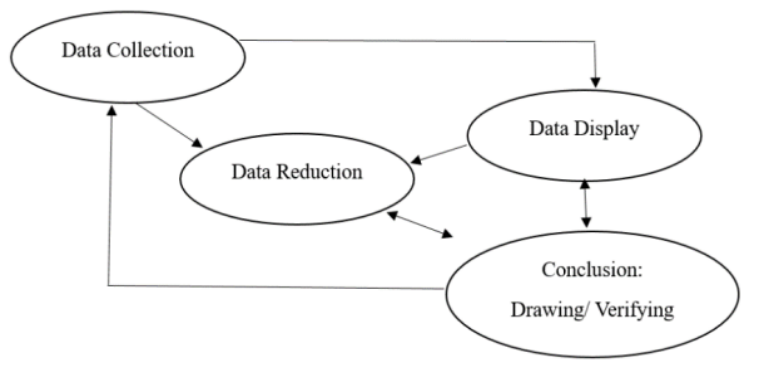

Figure 1. Technique and analysis Miles and Huberman (Adapted from Miles and Huberman, 1994, p. 10-11 cited in Baqi, 2014, p. 65).

The procedure of collecting data based on Figure 1 are (1) Making Consultation with chief of Tahfizh (Kepala Tahfizh), (2) Deciding participants of research based on the suggestion of head master of Tahfizh, (3) Doing observation during one month by giving them students' journal and observe them, (4) Doing the interview with the three participants, (5) Analyzing data, (6) Coding data. Prof (Participant's profile), TM (Time of begin memorizing al-Qur'an), PAK (Participant's Arabic-language knowledge), PAV (The Process to acquire Arabic vocabularies through memorizing al-Qur'an), PR (Parents' role), and EE (Environment effect). (7) Categorizing based on the themes, (8) Presenting data by chart to make easy in reading the report, (8) Concluding data, and (9) Reporting.

\subsection{Trustworthiness}

Merriam (2009, p. 209) states that validity and reliability in qualitative researcher is ethical manner. Validity and reliability are concern that can be approached through careful attention to study's conceptualization and the way in which the data are collected, analyzed, interpreted and the way in which the findings are presented (Merriam, 2009, p. 210). The three strategies will use for promoting validity and reliability of this research are triangulation, member checks, and rich, thick description.

\section{RESULTS}

\subsection{Data Description}

The source data come from observation and interview.

Table 4. The Result of Observation

\begin{tabular}{cccc}
\hline Subject & $\begin{array}{c}\text { Total } \\
\text { Words }\end{array}$ & $\begin{array}{c}\text { Acquiring Arabic } \\
\text { Words }\end{array}$ & Percentage \\
\hline Lidia & 2072 & 1501 & $72 \%$ \\
Asol & 3802 & 2464 & $65 \%$ \\
TRH & 3023 & 1715 & $57 \%$ \\
\hline Total & 8897 & 5680 & $64 \%$ \\
\hline
\end{tabular}

Table 5. Interview Categorize

\begin{tabular}{|c|c|c|c|c|}
\hline \multirow[t]{2}{*}{ Theme } & \multirow{2}{*}{$\begin{array}{l}\text { Theme } \\
\text { Name }\end{array}$} & \multicolumn{3}{|c|}{$\begin{array}{l}\text { Code Interview of Interview } \\
\text { Transcripts }\end{array}$} \\
\hline & & Asol & Lidia & TRH \\
\hline Prof & $\begin{array}{l}\text { Participant's } \\
\text { profile }\end{array}$ & $\begin{array}{l}\text { Prof Asol } \\
\text { 1, Prof } \\
\text { Asol } 2\end{array}$ & $\begin{array}{l}\text { Prof } \\
\text { Lidia }\end{array}$ & $\begin{array}{l}\text { Prof } \\
\text { THR }\end{array}$ \\
\hline TM & $\begin{array}{l}\text { Time of } \\
\text { beginning } \\
\text { memorizing } \\
\text { al-Qur'an }\end{array}$ & TM Asol & $\begin{array}{l}\text { TM } \\
\text { Lidia }\end{array}$ & TM TRH \\
\hline PAK & $\begin{array}{l}\text { Participant's } \\
\text { Arabic- } \\
\text { language } \\
\text { knowledge }\end{array}$ & $\begin{array}{l}\text { PAK } \\
\text { Asol 1, } \\
\text { PAK } \\
\text { Asol 2, } \\
\text { PAK } \\
\text { Asol 3, } \\
\text { PAK } \\
\text { Asol 4, } \\
\text { PAK } \\
\text { Asol 5, } \\
\text { PAK } \\
\text { Asol } 6\end{array}$ & $\begin{array}{l}\text { PAK } \\
\text { Lidia 1, } \\
\text { PAK } \\
\text { Lidia 2, } \\
\text { PAK } \\
\text { Lidia } 3\end{array}$ & $\begin{array}{l}\text { PAK } \\
\text { TRH 1, } \\
\text { PAK } \\
\text { TRH 2, } \\
\text { PAK } \\
\text { TRH } 3\end{array}$ \\
\hline PAV & $\begin{array}{l}\text { The Process } \\
\text { to acquire } \\
\text { Arabic } \\
\text { vocabularies } \\
\text { through } \\
\text { memorizing } \\
\text { al-Qur'an }\end{array}$ & $\begin{array}{l}\text { PAV } \\
\text { Asol 1, } \\
\text { PAV } \\
\text { Asol 2, } \\
\text { PAV } \\
\text { Asol 3, } \\
\text { PAV } \\
\text { Asol 4, } \\
\text { PAV } \\
\text { Asol 5. }\end{array}$ & $\begin{array}{l}\text { PAV } \\
\text { Lidia }\end{array}$ & $\begin{array}{l}\text { PAV } \\
\text { TRH 1, } \\
\text { PAV } \\
\text { TRH } 2\end{array}$ \\
\hline $\begin{array}{l}\mathrm{PR} \\
\mathrm{EE}\end{array}$ & $\begin{array}{l}\text { Parents' role } \\
\text { Environmen } \\
\text { t effect }\end{array}$ & $\begin{array}{l}\text { PR Asol } \\
\text { EE Asol } \\
1, \\
\text { EE Asol } \\
2, \text { EE } \\
\text { Asol } 3\end{array}$ & $\begin{array}{l}\text { PR Lidia } \\
\text { EE Lidia } \\
1, \text { EE } \\
\text { Lidia } 2\end{array}$ & $\begin{array}{l}\text { PR TRH } \\
\text { EE TRH } \\
1, \text { EE } \\
\text { TRH } 2\end{array}$ \\
\hline
\end{tabular}

(Adapted from interview between researcher and subjects of research on December 27, 2016.)

\begin{tabular}{|c|c|c|c|}
\hline \multicolumn{4}{|l|}{4000} \\
\hline \multicolumn{4}{|l|}{3500} \\
\hline \multicolumn{4}{|l|}{3000} \\
\hline \multicolumn{4}{|l|}{2500} \\
\hline 2000 & & & \\
\hline 1500 & & & \\
\hline \multicolumn{4}{|l|}{1000} \\
\hline \multicolumn{4}{|l|}{500} \\
\hline \multicolumn{4}{|c|}{ Lidia } \\
\hline Total Words & 2072 & 3802 & 3023 \\
\hline $\begin{array}{c}\text { Acquaring Arabic } \\
\text { Words }\end{array}$ & 1501 & 2464 & 1715 \\
\hline
\end{tabular}

Figure 2. Acquiring participants' Arabic vocabularies Chart 1. Acquiring participants' Arabic vocabularies

During the observation, Lidia memorized surah Ghafir, Fussilat, Ash-Shura, Az-Zukhruf, Al-Jathiya, and Al-Ahqaf. Total Arabic words of that surah are 
2072 words. She acquired Arabic words from that surah through memorizing them is 1501 words. It is about $72 \%$.

Then, during the observation, Asol memorized surah al-Jathiya, al-Ahqof, Muhammad, al-Fath, alHujurat, az-Zariyat, at-Tur, an-Najm, al-Qamar, alHadid, al-Qalam, Nuh, Jin, al-Muzammil, alMuddaththir, al-Qiyamah, al-Insan, and al-Mursalat. Total Arabic words of that surah are 3.802 words. She acquired 2.464 words, it about $65 \%$.

Then, the third subject is TRH. During the observation, she memorized ad-Dukhan, al-Jathiya, alAhqaf, Muhammad, al-Fath, al-Hujurat, Qaf, AdhDhariyat, at-Tur, and an-Najm. Total Arabic words of that surah are 3.023 words. She acquired 1.715 words, it about $57 \%$.

Total Arabic words that were memorized by them is 8.897 words; they acquired 5.680 words or $64 \%$. Lidia is the highest and TRH is the lowest one. Thus, the participants were able to acquire the meaning of $64 \%$ words that they memorized.

\subsection{Things that Influence Participants' Vocabulary Acquisition and Learning}

There are some things that influence in the process of acquiring languages such as the condition of parents' language, sex and participants' characteristics, participants' friends and environment.

\subsection{The condition of parents' Language}

The parents of Lidia, Asol, and TRH have no influence to their mastering in the Arabic language. For more information, see table (interview explanation). Lidia learns the Arabic language for the first time when she was a student of IV Elementary School; her first Arabic teacher was Miss. Leni. For the first time, she learns about dhomir such as hua huma hum, and unconsciously she acquires Arabic vocabularies. Then, Asol learns the Arabic language since class I Elementary School. Her first Arabic teacher is Mr. Masyudi. For the first time, she learns about the subject like ana means I and anti means you. The last subject is TRH. She learns the Arabic language since class I Elementary School. Her first Arabic teacher is Miss. Lusiana. For the first time, she learns about basic vocabularies such as "home" is bait.

\subsection{Participants' Friends and Environment}

Participants' Friends and Environment have a role to improve their abilities in the Arabic language. Usually, they make a conversation with the Arabic language with their friends in their daily activities. Lidia's environment has a role to acquire Arabic vocabularies. She made an Arabic conversation with her friends such as Sulis, Ratna, and her friends in the same grade. While a teacher has a little role. Asol's environment has a role in acquiring her Arabic vocabularies, especially her friends. She made an Arabic conversation with her friends such as Humaira, Nabilah Zulfa, Khonsa, and Rizkia. They teach each other and speak the Arabic language. But, if they do not know to speak Arabic, try to speak the English language. For instance, "Humaira, Ila aina?" (Where are you going?). Then, TRH's environment has a role in acquiring her Arabic vocabularies, especially her friends. She did make an Arabic conversation with her friends such as Amalia Ramadhani and Wiandita, for the example ayyu idamin hadzal yaum? (What is side dish today?). In her daily activity, she uses mix languages, sometimes Arabic, sometimes English, and sometime Bahasa. Thus, participants' friends and environments have a role in influence their acquiring Arabic words.

\section{FINDINGS}

Based on the process of analyzing the data, here are the findings of this research:

1. The participants were able to acquire the meaning of $64 \%$ words that they memorized

2. The participants' parents have no role in affecting participants' in acquiring Arabic vocabularies.

3. Friends and environments have a role in affecting participants' in acquiring Arabic vocabularies.

\section{DATA INTERPRETATION}

Lidia first language is the Javanese language; the second language is Bahasa Indonesia. The Arabic language becomes her third language. Asol and TRH's mother tongue is Bahasa Indonesia, the Arabic language becomes their second language. Related to Ellis's theory (2003: 3) that the term of "second" in second language acquisition means any language that is learned after the mother tongue, it can be referred to a third or fourth language.

The participants get Arabic vocabularies through memorizing al-Qur'an. Thus, they get those words in the unconscious process, it related with Krashen's theory (Brown and Hanlon, 1970; Brown, Cazden, and Bellugi, 1973; cited in Krashen 2002, p. 1). He said that Second language vocabulary acquisition is the unconscious process for getting vocabularies in the second language. Then, this research related to meaning based on Krashen's theory (Kreshen, 2002, p. 109)

\section{CONCLUSIONS}

Here are some conclusions of this research:

1. The participants were able to acquire the meaning of $64 \%$ words ( 5.680 words from 8.897 words) that they memorized. They acquire Arabic words through memorizing al-Qur'an with reading the texts more and more. Then, they always imagine the story that related with the surah's context.

2. The participants' parents have no role in affecting participants' in acquiring Arabic vocabularies.

3. Friends and environments have a role in affecting participants' in acquiring Arabic vocabularies. 


\section{SUGGESTIONS}

This result evidence that knowing the meaning (acquire word) could be done by a reading book that related with the language which expected. Thus, to learners who want to be master in the English language, they can read English magazine, English newspaper, English fiction books, or English scientific books without thinking or worrying about the meanings. By making reading as a habit, they will get many words unconsciously.

The next researchers who interest to study SLA, they can explore the other side of this research such as acquiring words or sentences through social media.

\section{REFERENCES}

Baqi, F. A. (2014). Employing Question-Answer Relationships (QAR) Strategy to Improve Students' Reading Comprehension (A classroom action research at the eleventh-year students of SMA Negeri 1 Rangkasbitung in 2012/ 2013 academic year). (thesis). Islamic State University Syarif Hidayatullah, Jakarta.

Brown, F. A. (2010). Vocabulary knowledge and Comprehension in Second Language Text Processing: A Reciprocal Relationship?. Asian EFL Journal, 12, pp. 88-133.

Coyle, Y., \& Gracia, R. G. (2014). Using the song to enhance L2 vocabulary acquisition in preschool children. ELT Journal, 68, pp. 276-285.

Crookes, G. (1997). SLA and language pedagogy. Journal of Cambridge University Press, 20, pp. 93-116.
Daskalovska, N. (2014). Reading and vocabulary acquisition. The International Journal of Foreign Language Teaching, 9 (2), pp. 2-8.

Ellis, R. (2003). Second Language Acquisition (9th Ed.). New York, NY. Oxford University Press.

Helms-Park, R. (2003). Transfer in SLA and creoles: The implications of causative serial verbs in the interlanguage of Vietnamese ESL learners. Journal of Cambridge University, 25, pp. 211-244.

Krashen, S. D. (2002). Second Language Acquisition and Second Language Learning. California, US: Pergamon Press.

Lyster, R. \& Saito, K. (2010). Oral feedback in classroom SLA. Journal of Cambridge University Press, 32, pp. 265-302.

Merriam, S. R. (2009). Qualitative Research: A Guide to Design and Implementation. Revised and Expanded from Qualitative Research and Case Study Applications in Education (2nd Ed). San Francisco, US: Jossey-Bass.

Naserieh, F. (2009). The Relationship between Perceptual Learning Style Preferences and Skill-based Learning Strategies (thesis). Shahid Beheshti University, Tehran.

Rognoni, L. \& Xavier, C. C. M. (2012). Thematic clustering in second language vocabulary learning scenarios versus mental scenes development. Asian EFL Journal, 14, pp. 69-80.

Yin, R. K., (2003). Case Study Research Design and Method $(3 r d E d)$. California, US: Sage Publication.

Yule, G. (2006). The Study of Language (3rd Ed). Cambridge, UK: Cambridge University Press. 